\title{
Paraneoplastic Myeloneuropathies
}

\section{Clinical, Oncologic, and Serologic Accompaniments}

Shailee Shah, MD, Rocio Vazquez Do Campo, MD, Neeraj Kumar, MD, Andrew McKeon, MD, Eoin P. Flanagan, MD, Christopher Klein, MD, Sean J. Pittock, MD, and Divyanshu Dubey, MD

Neurology ${ }^{\circledR}$ 2021;96:e632-e639. doi:10.1212/WNL.0000000000011218

\section{Correspondence}

Dr. Dubey

dubey.divyanshu@mayo.edu

\section{Abstract \\ Objective}

To test the hypothesis that myeloneuropathy is a presenting phenotype of paraneoplastic neurologic syndromes we retrospectively reviewed clinical, radiologic, and serologic features of 32 patients with concomitant paraneoplastic spinal cord and peripheral nervous system involvement.

\section{Methods}

Observational study investigating patients with myeloneuropathy and underlying cancer or onconeural antibody seropositivity.

\section{Results}

Among 32 patients with paraneoplastic myeloneuropathy, 20 (63\%) were women with median age 61 years (range $27-84$ years). Twenty-six patients (81\%) had classified onconeural antibodies (amphiphysin, $\mathrm{n}=8$; antineuronal nuclear antibody [ANNA] type 1 [anti-Hu], $\mathrm{n}=5$; collapsin response mediator protein 5 [CRMP5] [anti-CV2], $\mathrm{n}=6$; Purkinje cell cytoplasmic antibody type 1 [PCA1] [anti-Yo], $\mathrm{n}=1$; Purkinje cell cytoplasmic antibody type 2 [PCA2], $\mathrm{n}$ =2; kelch-like protein 11 [KLHL11], $\mathrm{n}=1$; and combinations thereof: ANNA1/CRMP5, $\mathrm{n}=$ 1; ANNA1/amphiphysin, $\mathrm{n}=1$; ANNA3/CRMP5, $\mathrm{n}=1$ ). Cancer was confirmed in 25 cases (onconeural antibodies, $\mathrm{n}=19$; unclassified antibodies, $\mathrm{n}=3$; no antibodies, $\mathrm{n}=3$ ). Paraneoplastic myeloneuropathies had asymmetric paresthesias (84\%), neuropathic pain (78\%), subacute onset $(72 \%)$, sensory ataxia (69\%), bladder dysfunction (69\%), and unintentional weight loss $>15$ pounds (63\%). Neurologic examination demonstrated concomitant distal or asymmetric hyporeflexia and hyperreflexia (81\%), impaired vibration and proprioception (69\%), Babinski response (68\%), and asymmetric weakness (66\%). MRI showed longitudinally extensive (45\%), tract-specific spinal cord T2 hyperintensities (39\%) and lumbar nerve root enhancement (38\%). Ten of 28 (36\%) were unable to ambulate independently at last follow-up (median 24 months, range 5-133 months). Combined oncologic and immunologic therapy had more favorable modified Rankin Scale scores at post-treatment follow-up compared to those receiving either oncologic or immunologic therapy alone (2 [range 1-4] vs 4 [range 2-6], $p<0.001)$.

\section{Conclusions}

Paraneoplastic etiologies should be considered in the evaluation of subacute myeloneuropathies. Recognition of key characteristics of paraneoplastic myeloneuropathy may facilitate early tumor diagnosis and initiation of immunosuppressive treatment.

From the Departments of Neurology (S.S., R.V.D.C., N.K., A.M., E.P.F., C.K., S.J.P., D.D.) and Laboratory Medicine and Pathology (A.M., E.P.F., C.K., S.J.P., D.D.), Mayo Clinic College of Medicine, Rochester, MN.

Go to Neurology.org/N for full disclosures. Funding information and disclosures deemed relevant by the authors, if any, are provided at the end of the article. 


\section{Glossary}

ANNA = antineuronal nuclear antibody; CRMP5 = collapsin response mediator protein 5; IgG = immunoglobulin G; KLHL11 = kelch-like protein s11; MAP1B = microtubule-associated protein 1B antibody; mRS = modified Rankin Scale; PCA = Purkinje cell cytoplasmic antibody

Myeloneuropathies are defined by the concomitant development of peripheral nerve and spinal cord involvement. ${ }^{1,2}$ Etiologies usually associated with myeloneuropathy include metabolic (vitamin $\mathrm{B}_{12}$ or copper deficiency), inflammatory, infectious, hereditary, or toxic. Paraneoplastic neurologic syndrome diagnostic criteria (2004) included paraneoplastic encephalomyelitis, limbic encephalitis, cerebellar degeneration, subacute sensory neuronopathy, and chronic gastrointestinal pseudo-obstruction as classical paraneoplastic phenotypes. ${ }^{3}$ Paraneoplastic myelopathy and sensorimotor neuropathy were individually described as nonclassical syndrome but paraneoplastic myeloneuropathy was not specifically described.

Myelopathy and neuropathy as manifestations of paraneoplastic disorders have been described in association with breast and lung cancers. ${ }^{4,5}$ These may occur in isolation or as part of a multifocal neurologic disorder, primarily due to immune targeting of intracellular neural antigens. The sequential development of myelopathy and neuropathy has been described in cases of breast adenocarcinoma or small cell lung cancer, particularly in association with amphiphysin-immunoglobulin G (IgG), or antineuronal nuclear antibody (ANNA) type 1 (anti-Hu), but the concomitant development of neuropathy and myelopathy in paraneoplastic disorders remains largely limited. ${ }^{6,7}$ Case reports of myeloneuropathy in association with testicular cancer with anti-Ma2IgG and breast cancer have been reported. ${ }^{8-11}$ Patients with underlying cancers have also been reported to develop nutritional deficiency myeloneuropathies, posing a diagnostic dilemma. ${ }^{12,13}$ Therefore, recognition of clinical characteristics that can help identify paraneoplastic etiologies may aid in earlier diagnosis and management. ${ }^{14}$ Herein, we describe a single-center cohort of patients with paraneoplastic myeloneuropathy, and review the associated diagnostic characteristics.

\section{Methods}

\section{Standard Protocol Approvals, Registration, and Patient Consents}

The study was approved by the institutional review board of Mayo Clinic, Rochester, Minnesota (institutional review board number 08-006647). Electronic medical records and neuroimmunology laboratory databases between 1995 and 2019 were used to identify patients with clinical, radiographic, or electrodiagnostic evidence of myelopathy and peripheral neuropathy. ${ }^{15-17}$

Patients with concomitant development of peripheral nerve or root, and spinal cord involvement within a 3-month timeframe with supporting evidence of multifocal involvement in both clinical and radiographic or electrodiagnostic domains were included. Cases with coexisting encephalopathy at onset or isolated motor neuron involvement were excluded.

Paraneoplastic association was defined by presence of onconeural autoantibody in the serum with $>70 \%$ neoplastic association or a diagnosis of neoplasm within 3 years of symptom onset and exclusion of alternative causes such as multiple sclerosis or neuromyelitis optica spectrum disorder. ${ }^{3}$ Furthermore, patients with vitamin $\mathrm{B}_{12}$ or copper deficiency, HIV infection, prominent neuropathy attributed to chemotherapy by historical documentation, and neoplastic infiltration of the CNS were excluded.

Search terms used to identify cases included myeloneuropathy, paraneoplastic myelopathy, paraneoplastic neuropathy, paraneoplastic sensory neuronopathy, paraneoplastic polyradiculoneuropathy, paraneoplastic motor neuron disease, and paraneoplastic encephalomyelitis. Laboratory databases by discrete onconeural antibody positivity (collapsin response mediator protein 5 [CRMP5], ANNA1, amphiphysin, Purkinje cell cytoplasmic antibody [PCA] type 2) and cancers (breast adenocarcinoma, small cell lung cancer, testicular cancer) were also used to identify patients. ${ }^{7,18-23}$

Medical records of patients who met the stated criteria were reviewed by 3 neurologists (S.S., R.V.D.C., D.D.) for demographic, clinical, electrophysiologic, and radiographic data. Outcomes were measured by ambulatory status and by change in modified Rankin Scale (mRS) score before treatment and at last follow-up in those patients with available outcome data. A decrease in $\mathrm{mRS}$ scores of $\geq 1$ was considered to be a favorable response.

\section{Laboratory Methods}

All patients were evaluated for onconeural antibodies to various specificities: ANNA1, ANNA2, ANNA3, CRMP5, antiglial/neuronal nuclear antibody (AGNA1, or SOX1), amphiphysin, PCA1, microtubule-associated protein 1B antibody (MAP1B; PCA2), and kelch-like protein 11 (KLHL11) in the Mayo Clinic Neuroimmunology Laboratory. ${ }^{17-19,22,24,25}$

\section{Indirect Immunofluorescence Assay for Antibody Detection}

Patient sera were tested by indirect tissue-based indirect immunofluorescence on a cryosectioned $(4 \mu \mathrm{m})$ composite of adult mouse cerebellar, midbrain, cerebral cortex, hippocampus, 
kidney, and gut tissue, as previously described. ${ }^{19,20}$ Samples with characteristic staining patterns were titrated in doubling dilutions to determine the endpoint titer.

\section{Recombinant Protein Western Blot/HEK293 Cells Overexpression Assay}

Amphiphysin, MAP1B, and CRMP5 antibody specificities were confirmed by Western blot analysis using recombinant human amphiphysin protein (full length), MAP1B fragment (amino acids 1-666), and CRMP5 (full-length), respectively. ${ }^{15,25}$ KLHL11 IgG detected on tissue immunofluorescence was confirmed by KLHL11 HEK293 overexpression cell-based assay. ${ }^{22,26}$

\section{Statistical Analysis}

Descriptive data were reported using medians, ranges, and percentages. Categorical and continuous variables were analyzed by Mann-Whitney $U$ testing. The $p$ value was 2 -sided and $p$ values less than 0.05 were significant (JMP Pro 14).

\section{Data Availability}

All Methods are available above and data are published in this article.

\section{Results}

\section{Demographics, Antibody, and Oncologic Associations}

Thirty-two patients had paraneoplastic myeloneuropathy as their initial presentation (table). Twenty were women (63\%) and median age was 61 years (range 27-84 years). Chronic tobacco use was noted in $81 \%$ of patients (median 40 packs per year, $\mathrm{n}=26$ ). Underlying malignancy was detected in 25 patients. Small cell lung cancer $(\mathrm{n}=11)$ and breast adenocarcinoma $(n=7)$ were the most common malignancies, with further details shown in figure 1. Neurologic symptoms manifested prior to cancer diagnosis in $22 / 25$ patients and the remaining 3 cases had symptom onset within 3 years of cancer diagnosis.

Among 32 patients with paraneoplastic myeloneuropathy, 20 had antibody evaluations in the serum and 12 had both serum and CSF neural-specific antibody testing. Twenty-six had detectable onconeural antibodies: amphiphysin, $n=8$ (serum only, $\mathrm{n}=4$; CSF and serum, $\mathrm{n}=4$; median serum titer 1:3,840; range 1:240-1:245,760 [normal < 1:120]; median CSF titer 1:64, range 1:4-1:960 [normal < 1:4]); ANNA1 (anti-Hu), n $=5$ (serum only, $\mathrm{n}=4$; CSF and serum, $\mathrm{n}=1$, median serum titer 1:3,840, range 1:240-1:122,880; CSF titer 1:512); CRMP5, $\mathrm{n}=6$ (serum only, $\mathrm{n}=3$; CSF and serum, $\mathrm{n}=3$, median serum titer 1:3,840, range 1:240-1:491,520; median CSF titer 1:512, range 1:64-1:8,192); PCA1 (anti-Yo), $\mathrm{n}=1$ (serum titer 1:240; CSF titer 1:16); PCA2 (MAP1B), $\mathrm{n}=2$ (serum only, titers 1:240; 1:15,360); KLHL11, $\mathrm{n}=1$ (serum titer 1:240 and CSF titer 1:4); and combinations thereof: ANNA1/CRMP5, $\mathrm{n}=1$ (serum titer 1:960/1:240); ANNA1/ amphiphysin, $\mathrm{n}=1$ (serum titer 1:61,440/1:30,720; CSF titer
1:4/1:1,024); ANNA3/CRMP5, $\mathrm{n}=1$ (ANNA3 serum titer 1:960, CRMP5 detected in both serum and CSF, serum titer 1:7,680 and CSF titer 1:1,024). Nineteen of these 26 patients were diagnosed with cancers. The remaining $7 \mathrm{pa}-$ tients had imaging findings suggestive of neoplasm, but pathologic confirmation was not available (figure 1). Among these, 1 patient had a breast mass, 4 had lung masses, and 2 had abdominal masses. Biopsy and histopathologic analysis in 2 of these 7 cases was nondiagnostic. In 3 patients, data regarding biopsy/histopathologic evaluation of the mass was not present in the patient records. In 2 patients, rapid neurologic deterioration and superimposed infection led to death prior to attempting biopsy. All 6 patients without characterized onconeural antibodies (unclassified neural specific antibodies, $\mathrm{n}=3$ [ 2 detected in serum, and 1 detected in both serum and CSF]) had pathologically confirmed cancer.

\section{Clinical Characteristics}

Patients frequently had a subacute presentation, defined as nadir of symptom severity occurring 1 to 3 months from onset $(\mathrm{n}=23,72 \%)$. Two patients (6\%) presented acutely within 1 month and 7 (22\%) presented with a more chronic decline. Most common clinical characteristics included neuropathic pain $(\mathrm{n}=25,78 \%)$, bladder dysfunction $(\mathrm{n}=22,69 \%)$, asymmetric paresthesias $(n=20,63 \%)$, and unintentional weight loss of greater than 15 pounds $(n=20,63 \%$; median weight loss 20 pounds [range 15-75]). Neuropathic symptoms were non-length-dependent $(\mathrm{n}=28,88 \%)$ and radicular involvement was noted in 56\% $(\mathrm{n}=18)$ of patients. Patients commonly had cramping, spasms, or stiffness $(n=17,53 \%)$, and in 2 patients with amphiphysin autoantibodies, simultaneous peripheral nerve hyperexcitability. Orthostatic intolerance defined by clinical history of syncope or lightheadedness and blood pressure changes upon standing was seen in 14 patients (44\%) with supportive autonomic reflex testing in 4 patients. Gastrointestinal dysmotility at onset, defined as new, severe postprandial fullness or nausea, constipation, or diarrhea $(\mathrm{n}=14,44 \%)$ was also common; 1 patient had gastric motility studies, which demonstrated prolonged colonic and small bowel emptying.

Neurologic examination commonly demonstrated simultaneous hyporeflexia and hyperreflexia at different sites $(n=26$, $81 \%$ ). Hyporeflexia was usually present distally or in an asymmetric pattern. The majority of patients also had impaired vibration and proprioception $(n=22,69 \%)$, Babinski response $(n=22,68 \%)$, and asymmetric weakness $(n=21$, $66 \%)$. Weakness was noted in both upper and lower limbs in $44 \%$ of patients $(n=14)$. Thirty-seven percent $(n=12)$ of patients had isolated lower limb involvement and 19\% ( $\mathrm{n}=6)$ had isolated upper limb involvement.

Copper or vitamin $B_{12}$ deficiency related subacute combined degeneration was the primary diagnostic consideration at disease onset in 28 patients ( $88 \%$ ) but was excluded by pertinent laboratory investigation. Among patients with CSF analysis $(\mathrm{n}=28)$, the majority $(23,82 \%)$ had inflammatory 
Table Clinical Characteristics, Diagnostic Studies, and Outcomes of Paraneoplastic Myeloneuropathies

\begin{tabular}{|c|c|}
\hline & $\begin{array}{l}\text { N/total } \\
\text { n (\%) }\end{array}$ \\
\hline \multicolumn{2}{|l|}{ Clinical characteristics } \\
\hline Age at onset, $y$, mean (range) & $61(27-84)$ \\
\hline Female & $20 / 32(63)$ \\
\hline Subacute onset & $23 / 32(72)$ \\
\hline Neuropathic pain & $25 / 32(78)$ \\
\hline Sensory ataxia & $22 / 32(69)$ \\
\hline Asymmetric sensory abnormalities & $22 / 32(69)$ \\
\hline Vibration and proprioception loss & $22 / 32(69)$ \\
\hline Bladder dysfunction & $22 / 32(69)$ \\
\hline Babinski response & $22 / 32(68)$ \\
\hline Asymmetric weakness & $21 / 32(66)$ \\
\hline Unintentional weight loss & $20 / 32(63)$ \\
\hline Orthostastic intolerance & $14 / 32(44)$ \\
\hline Gastrointestinal dysmotility & $14 / 32(44)$ \\
\hline Malignancies identified (pathologically confirmed) & $25 / 32(78)$ \\
\hline \multicolumn{2}{|l|}{ MRI characteristics } \\
\hline $\begin{array}{l}\text { Intramedullary T2 hyperintensities involving MRI } \\
\text { spine }\end{array}$ & $19 / 31(61)$ \\
\hline $\begin{array}{l}\text { Longitudinally extensive } \mathrm{T} 2 \text { lesion (>3 vertebral } \\
\text { segments) }\end{array}$ & $14 / 31(45)$ \\
\hline Tract-specific $\mathrm{T} 2$ hyperintensities & 12/31 (39) \\
\hline Lumbar root enhancement & $8 / 21(38)$ \\
\hline Intramedullary spinal cord enhancement & $11 / 31(35)$ \\
\hline Gray matter involvement & 9/31 (29) \\
\hline \multicolumn{2}{|l|}{ CSF characteristics } \\
\hline Elevated CSF protein, $>50 \mathrm{mg} / \mathrm{dL}$ & $22 / 28(79)$ \\
\hline CSF elevated white blood cell count, $>5$ cells $/ \mu \mathrm{L}$ & $17 / 29(59)$ \\
\hline Supernumerary CSF oligoclonal bands & $11 / 21(52)$ \\
\hline \multicolumn{2}{|l|}{ Clinical outcomes } \\
\hline Wheelchair dependent at attack nadir & $20 / 32(63)$ \\
\hline Clinical improvement & $15 / 28(54)$ \\
\hline Wheelchair bound at last follow-up & $10 / 28(36)$ \\
\hline Duration of follow-up, median (range), mo & $24(5-133)$ \\
\hline
\end{tabular}

changes (median CSF cell count 8 cells $/ \mathrm{mm}^{3}$, range 0-74 cells $/ \mathrm{mm}^{3}$ [lymphocytic predominant] and median CSF protein $73 \mathrm{mg} / \mathrm{dL}$, range $31-188 \mathrm{mg} / \mathrm{dL}$ ). Four patients did not have CSF collected; 2 had normal spine MRIs, but both were positive for amphiphysin autoantibodies and had breast or small-cell lung cancer, respectively.
MRI Characteristics of Patients With Paraneoplastic Myeloneuropathy

Several notable imaging findings were observed, and representative images are provided in figure 2. Imaging was not available for review in 1 patient. Spinal cord T2 hyperintensities were present in 19 patients (61\%), and 14 (45\%) were longitudinally extensive ( $\geq 3$ vertebral segments) T2 lesions (table). Twelve patients (39\%) did not demonstrate any spinal cord MRI abnormalities, despite myelopathic findings on examination. T2 hyperintensities were tractspecific in 12 of the 19 (63\%) abnormal MRIs and dorsal columns $(n=6)$, lateral corticospinal tract $(n=5)$, or both dorsal column and corticospinal tracts $(\mathrm{n}=1)$ (figure 2). Central gray matter abnormalities were also identified in 9 patients (29\%). Half of the tract-specific lesions $(n=6,50 \%)$ had bilaterally symmetric involvement of the spinal cord tracts. Approximately one-third of patients $(\mathrm{n}=11,35 \%)$ demonstrated active contrast extravasation. Ten patients (32\%) demonstrated nerve root contrast enhancement, 8 limited to the lumbar roots (figure 2).

\section{Neuropathy Characteristics}

Electrodiagnostic studies were performed in 31 patients, and all had electrophysiologic features suggestive of an axonal neuropathy. One patient additionally had some features of demyelination on nerve conduction studies, presumed secondary to axonal loss. One patient with clinically evident neuropathy did not undergo electrodiagnostic study. Clinical description of neuropathic pain radiating down one or more dermatomal distributions with proximal muscle weakness or evidence of denervation in the paraspinal muscles was considered indicative of radicular involvement. Polyradiculoneuropathy with evidence of nerve root and peripheral nerve involvement was the most common neuropathy phenotype $(n=16,50 \%)$, closely followed by distal, asymmetric sensorimotor neuropathy $(\mathrm{n}=$ 10, 31\%). Sensory ganglionopathy and symmetric lengthdependent sensorimotor neuropathies were present in 2 and 4 patients, respectively.

Somatosensory evoked potentials performed in 2 patients demonstrated impairment in both central and peripheral proprioceptive pathways. Autonomic reflex testing was performed in 4 patients. Two patients had moderate to severe cardiovagal, adrenergic, and postganglionic sudomotor dysfunction. One had adrenergic and postganglionic sudomotor dysfunction and another had moderate to severe cardiovagal and adrenergic impairments with preserved postganglionic sudomotor function, suggesting a limited autonomic failure.

\section{Management and Clinical Outcomes}

Ten patients received only immunotherapy, 3 received only oncologic therapy, and 16 received both. First-line immunotherapies included 1 or more of the following: high-dose IV methylprednisolone $(\mathrm{n}=19)$, IV immunoglobulin $(\mathrm{n}=12)$, oral prednisone $(n=12)$, or plasmapheresis $(n=4)$. A subset of these patients received long-term immunosuppression: cyclophosphamide $(n=9)$, rituximab $(n=2)$, mycophenolate 
A. Onconeural antibodies

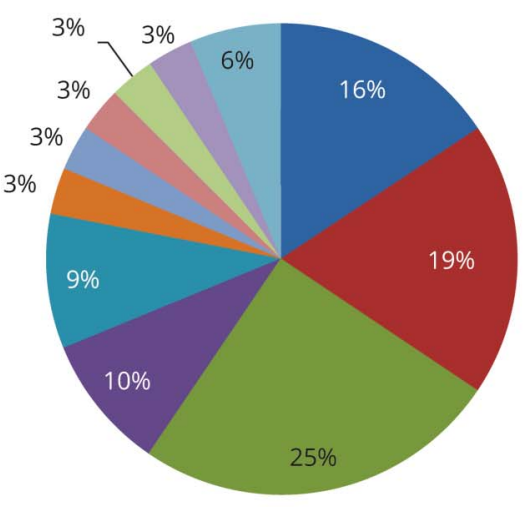

B. Cancer association

- ANNA1
- CRMP5
- Amphiphysin
- None
- Unclassified
- CRMP5/ANNA1
- CRMP5/ANNA3
- KHLH-11
- PCA1
- PCA2

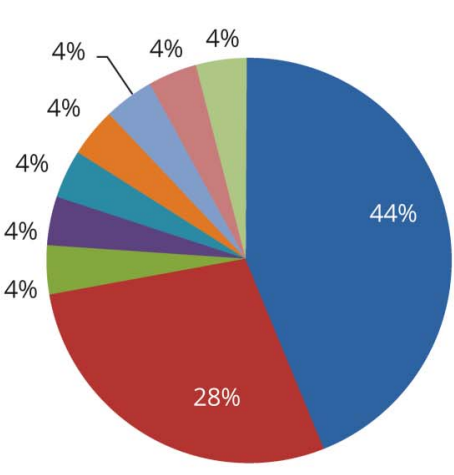

- Small cell lung cancer

- Breast adenocarcinoma

- Neuroendocrine tumor

- Non-small cell lung cancer

n Diffuse large B-cell lymphoma

nelanoma

- Renal cell carcinoma

n Seminoma

n Endometrial carcinoma

(A) Summary of onconeural antibodies and presence of cancer; 3 patients had unclassified neural specific antibodies. (B) Cancer association in 25 patients. Among 7 patients, no neoplasms were identified. ANNA1 = antineuronal nuclear antibody type 1 (anti-Hu); ANNA3 = antineuronal nuclear antibody type 3; CRMP5 = collapsin response mediator protein 5 (CV2); PCA1 = Purkinje cell cytoplasmic antibody type 1; KLHL11 = kelch-like protein 11.

mofetil $(\mathrm{n}=2)$, and azathioprine $(\mathrm{n}=2)$. Three seropositive patients without pathologic diagnosis of neoplasm did not receive oncologic or immunologic therapy.

Median duration of follow-up was 24 months (range 5-133 months). Fifteen of 28 patients (53\%) with long-term follow- up (>1 year follow-up) had favorable clinical outcomes with cancer treatment or immunotherapy at subsequent follow-up. Another 6 patients stabilized, whereas 7 continued to deteriorate despite therapy. At last known follow-up, 7 patients (22\%) had died. Median follow-up for patients without identified malignancies was 11 months (range 10-20).
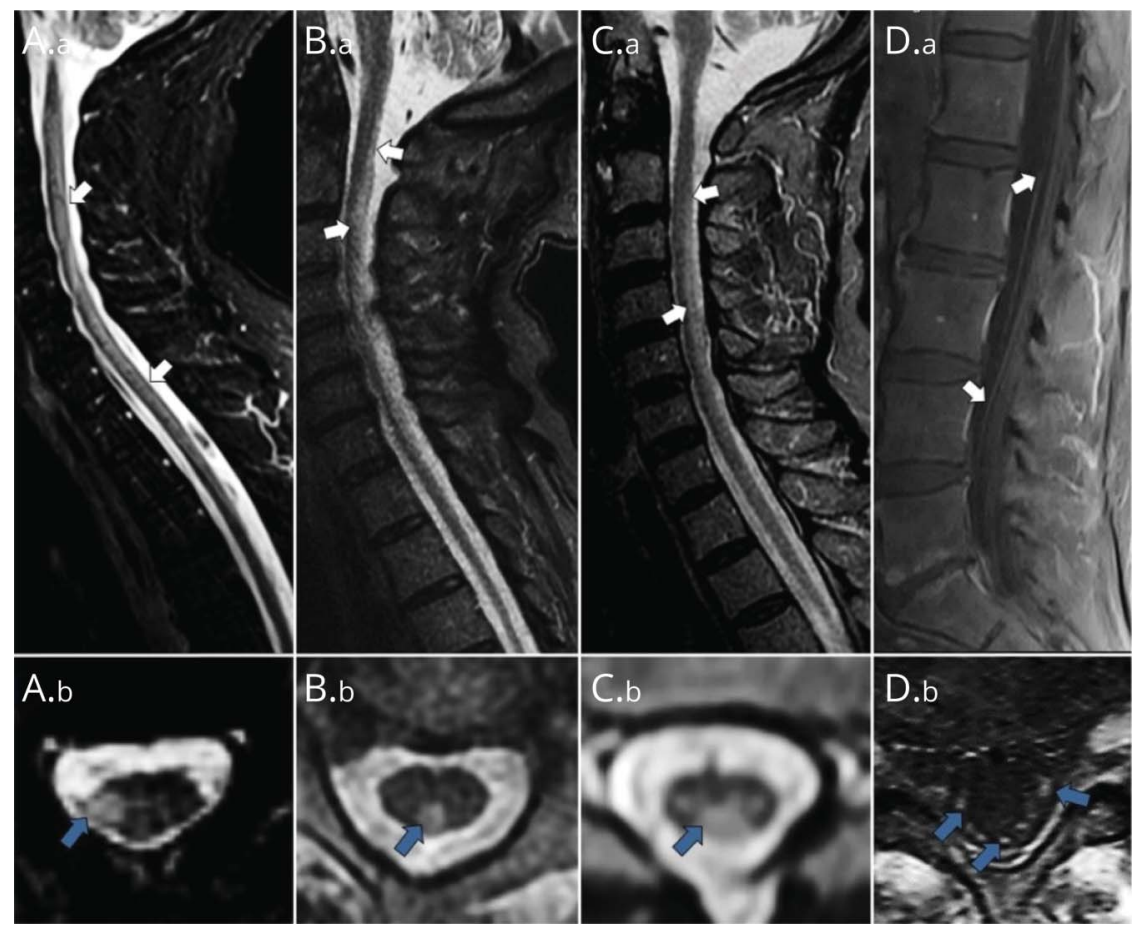

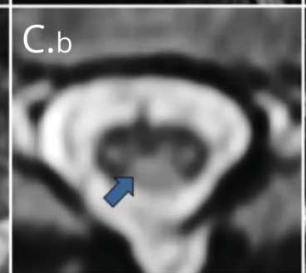

Cervical, thoracic, and lumbar spine MRI sagittal (A.a, B.a, C.a, D.a) and axial (A.b, B.b, C.b, D.b) sequences. (A.a, A.b) Collapsin response mediator protein 5 (CRMP5) (CV2) immunoglobulin G (IgG)-seropositive adult patient with asymmetric, longitudinally extensive T2-hyperintense lesion (white arrow) involving the right corticospinal tracts (blue arrow) with a concomitant axonal polyradiculoneuropathy. (B.a, B.b) Antineuronal nuclear antibody type 1 (anti-Hu) (ANNA1) and amphiphysin IgG-seropositive adult patient with longitudinally extensive T2-hyperintense lesion (white arrow) involving the right dorsal column (blue arrow) with a concomitant sensory neuronopathy. (C.a, C.b) ANNA1 IgG-seropositive adult patient with symmetric, bilateral, longitudinally extensive T2-hyperintense lesion (white arrow) involving the dorsal columns (blue arrows) and concomitant sensory predominant length dependent axonal polyneuropathy. (D.a, D.b) Adult patient with unclassified neural specific antibody with diffuse nerve roots enhancement on postgadolinium T1-weighted sagittal (white arrow) and axial (blue arrow) sequences. 
In patients receiving a combination of oncologic and immunologic therapy, outcomes were significantly favorable (median change in mRS before and after treatment) in comparison to those receiving either oncologic or immunologic therapy alone $(-2$ range -3 to 0$]$ vs 0 [range -1 to $2], p<0.001)$. Furthermore, median mRS at posttreatment follow-up among the patients receiving combination therapy was significantly lower than patients receiving either oncologic or immunologic therapy alone (2 [range 1-4] vs 4 [range 2-6] $p<0.001)$.

\section{Discussion}

Paraneoplastic myeloneuropathies exist as their own unique clinical phenotype and may be a diagnostic consideration in the evaluation of myeloneuropathies. Key presenting features of paraneoplastic myeloneuropathy are subacute asymmetric weakness and paresthesias, severe neuropathic pain, sensory ataxia, bladder dysfunction, and orthostatic intolerance. Examination reveals concomitant hyporeflexia and hyperreflexia, Babinski response, asymmetric weakness and numbness, and impaired vibration and proprioception. Diagnostic workup was remarkable for longitudinally extensive, tract-specific T2-hyperintense spinal cord lesions, spinal cord or nerve root gadolinium enhancement, and inflammatory CSF. In this study, wheelchair dependence at disease nadir among patients with paraneoplastic myeloneuropathy was noted in a little more than half of the patients.

Gastrointestinal dysmotility and orthostatic intolerance seen in several patients was similar to previously reported paraneoplastic neuropathy studies. ${ }^{15,18}$ This may be primarily due to postganglionic autonomic nerve dysfunction, as suggested by the quantitative sudomotor axon reflex changes noted among all patients who underwent autonomic reflex screen. However, dysfunction of sympathetic or parasympathetic preganglionic neuronal tracts within the spinal cord may also have some contribution. ${ }^{4,27}$

Some of these distinguishing characteristics, especially sensory ataxia, have been highlighted in prior case reports of paraneoplastic myeloneuropathies. ${ }^{8,9,11}$ Longitudinally extensive tract-specific changes on MRI have been similarly reported in a patient with seronegative paraneoplastic myeloneuropathy associated with breast cancer. ${ }^{8}$ Autoimmune myeloneuropathies without a strong oncologic association have also been described among patients with adaptor protein $3 \mathrm{~B} 2$ autoimmunity and Sjögren syndrome. ${ }^{28,29}$

In our study, small cell lung cancer and breast adenocarcinoma were the most common oncologic associations (53\%), similar to prior reports of paraneoplastic myelopathies or neuropathies. ${ }^{4,17,30}$ The majority of cancers were detected at an early stage $(n=18,72 \%)$, supportive of either a potent anticancer immune response or indicative of earlier cancer detection due to paraneoplastic neurologic manifestations. ANNA1, CRMP5, and amphiphysin were the most common autoantibody specificities noted (figure 1). Intracellular localization of the autoantigens for the majority of these antibodies supports the significant role of autoantigen-specific T-cell response among these cases. ${ }^{31}$ These findings demonstrate that paraneoplastic myeloneuropathy presentation, similar to other classic or nonclassic paraneoplastic phenotypes, can be seen in association with various onconeural antibodies and cancers. ${ }^{3}$

Comprehensive neuropathologic analysis of well-characterized paraneoplastic myeloneuropathy is lacking. However, histopathologic assessment of spinal cord and nerve biopsies of patients presenting with paraneoplastic myelopathy or neuropathy has demonstrated perivascular cuffing of CD8+ $\mathrm{T}$ lymphocytes, supporting a cytotoxic $\mathrm{T}$ cell-mediated pathogenesis. ${ }^{18,32}$ Concern may exist regarding immunosuppression reducing anticancer response or potential drug interactions with other cancer chemotherapies; however, the majority of patients with myeloneuropathy who received early, combined cancer and immunosuppressive therapy had favorable long-term clinical outcomes. ${ }^{33}$ This dual approach of removal of antigen source and immune response suppression has been successfully utilized in classical PNS. ${ }^{34}$

Paraneoplastic myeloneuropathy phenotype differs from paraneoplastic motor neuron disease, due to predominance of sensory involvement. ${ }^{35}$ Due to lack of encephalitis among these cases, the term "encephalomyelitis" does not provide accurate information about the neurologic localization of this paraneoplastic phenotype. ${ }^{3}$ Longitudinally extensive tract-specific MRI findings (figure 2) are common among paraneoplastic myeloneuropathies, and have also been described in isolated paraneoplastic myelopathies. ${ }^{4,24}$ These radiographic features are distinct from demyelinating diseases such as multiple sclerosis, which are characterized by shorter segment, asymmetric lesions. ${ }^{36,37}$ Copper deficiency can present with myeloneuropathy with symmetric dorsal column abnormalities on imaging, but can be distinguished by its chronic disease course and lack of associated neuropathic pain. ${ }^{38,39}$ Other notable radiographic findings such as central gray matter involvement and gadolinium enhancement of the intramedullary spinal cord and nerve roots can also help distinguish this syndrome from metabolic myeloneuropathies. It is important to note that few patients with paraneoplastic myeloneuropathy did not have imaging abnormalities but had other supportive clinical and paraclinical findings including inflammatory CSF supportive of immunemediated pathogenesis.

This is a retrospective study and some cases had limited longterm follow-up data. A limitation of this approach includes the potential to overlook this entity if clinical diagnosis or identifiable terminology was not included in clinical documentation, particularly patients in whom diagnostic evaluations were performed between several institutions. Longer follow-up and 
repeated cancer screenings may have provided more definitive evidence of neoplasm and highlights the importance of the guideline-driven approach to repeat testing at 6-to 12-month intervals for 2 years when suspecting paraneoplastic neurologic syndrome. ${ }^{3,40,41}$

The observations from our study may provide insights into this rare yet distinguishable paraneoplastic phenotype. ${ }^{14}$ Clinical recognition of this subacute myeloneuropathy phenotype may result in early cancer diagnosis, and favorable neurologic outcomes with combined oncologic and immunosuppressive therapy.

\section{Acknowledgment}

The authors thank S. Vinje for administrative assistance.

\section{Study Funding}

No targeted funding reported.

\section{Disclosure}

Shailee Shah, Rocio Vazquez Do Campo, and Neeraj Kumar report no relevant disclosures. Andrew McKeon has a patent pending for KLHL11, Septin 5, and MAP1B as markers of neurologic autoimmunity and paraneoplastic disorders. Eoin P. Flanagan is a site principal investigator in a randomized placebocontrolled clinical trial of inebilizumab (a cluster of differentiation 19 inhibitor) in neuromyelitis optica spectrum disorders funded by MedImmune/Viela Bio and receives research funding from the $\mathrm{NIH}$, National Institute of Neurologic Disorders and Stroke (R01NS113828). Christopher Klein reports no relevant disclosures. Sean J. Pittock is a named inventor on filed patents that relate to functional AQP4/NMO-IgG assays and NMO-IgG as a cancer marker; has a patent pending for KLHL11-IgG, Septin 5, and MAP1B IgGs as markers of neurologic autoimmunity and paraneoplastic disorders; has consulted for Alexion and Medimmune; and has received research support from Grifols, Medimmune, and Alexion. All compensation for consulting activities is paid directly to Mayo Clinic. Divyanshu Dubey has received research support from Center of Multiple Sclerosis and Autoimmune Neurology, Center for Clinical and Translational Science, and Grifols Pharmaceuticals; and has consulted for UCB and Astellas Pharmaceuticals. All compensation for consulting activities is paid directly to Mayo Clinic. Dr. Dubey has a patent pending for KLHL11-IgG as a marker of neurologic autoimmunity. Go to Neurology.org/ $\mathrm{N}$ for full disclosures.

\section{Publication History}

Received by Neurology April 23, 2020. Accepted in final form September 21, 2020.

Appendix Authors

\begin{tabular}{lll}
\hline Name & Location & Contributions \\
\hline $\begin{array}{l}\text { Shailee Shah, } \\
\text { MD }\end{array}$ & $\begin{array}{l}\text { Mayo } \\
\text { Clinic }\end{array}$ & $\begin{array}{l}\text { Acquired the data, analyzed the data, } \\
\text { interpreted the data, drafted the } \\
\text { manuscript, revised the manuscript for } \\
\text { intellectual content }\end{array}$ \\
\hline
\end{tabular}

Appendix (continued)

\begin{tabular}{|c|c|c|}
\hline Name & Location & Contributions \\
\hline $\begin{array}{l}\text { Rocio Vazquez } \\
\text { Do Campo, MD }\end{array}$ & $\begin{array}{l}\text { Mayo } \\
\text { Clinic }\end{array}$ & $\begin{array}{l}\text { Acquired the data, interpreted the data, } \\
\text { revised the manuscript for intellectual } \\
\text { content }\end{array}$ \\
\hline $\begin{array}{l}\text { Neeraj Kumar, } \\
\text { MD }\end{array}$ & $\begin{array}{l}\text { Mayo } \\
\text { Clinic }\end{array}$ & $\begin{array}{l}\text { Interpreted the data, revised the } \\
\text { manuscript for intellectual content }\end{array}$ \\
\hline $\begin{array}{l}\text { Andrew } \\
\text { McKeon, MD }\end{array}$ & $\begin{array}{l}\text { Mayo } \\
\text { Clinic }\end{array}$ & $\begin{array}{l}\text { Interpreted the data, revised the } \\
\text { manuscript for intellectual content }\end{array}$ \\
\hline $\begin{array}{l}\text { Eoin P. Flanagan, } \\
\text { MD }\end{array}$ & $\begin{array}{l}\text { Mayo } \\
\text { Clinic }\end{array}$ & $\begin{array}{l}\text { Interpreted the data, revised the } \\
\text { manuscript for intellectual content }\end{array}$ \\
\hline $\begin{array}{l}\text { Christopher } \\
\text { Klein, MD }\end{array}$ & $\begin{array}{l}\text { Mayo } \\
\text { Clinic }\end{array}$ & $\begin{array}{l}\text { Interpreted the data, revised the } \\
\text { manuscript for intellectual content }\end{array}$ \\
\hline $\begin{array}{l}\text { Sean J. Pittock, } \\
\text { MD }\end{array}$ & $\begin{array}{l}\text { Mayo } \\
\text { Clinic }\end{array}$ & $\begin{array}{l}\text { Interpreted the data, revised the } \\
\text { manuscript for intellectual content }\end{array}$ \\
\hline $\begin{array}{l}\text { Divyanshu } \\
\text { Dubey, MD }\end{array}$ & $\begin{array}{l}\text { Mayo } \\
\text { Clinic }\end{array}$ & $\begin{array}{l}\text { Designed and conceptualized study, } \\
\text { analyzed the data, drafted the } \\
\text { manuscript, revised the manuscript for } \\
\text { intellectual content, study supervision }\end{array}$ \\
\hline
\end{tabular}

\section{References}

1. Goodman BP. Diagnostic approach to myeloneuropathy. Continuum 2011;17: 744-760.

2. Garg RK, Malhotra HS, Kumar N. Approach to a case of myeloneuropathy. Ann Indian Acad Neurol 2016;19:183-187.

3. Graus F, Delattre JY, Antoine JC, et al. Recommended diagnostic criteria for paraneoplastic neurological syndromes. J Neurol Neurosurg Psychiatry 2004;75:1135-1140.

4. Zalewski NL, Flanagan EP. Autoimmune and paraneoplastic myelopathies. Semin Neurol 2018;38:278-289.

5. Graus F, Keime-Guibert F, Rene R, et al. Anti-Hu-associated paraneoplastic encephalomyelitis: analysis of 200 patients. Brain 2001;124:1138-1148.

6. Zekeridou A, McKeon A, Lennon VA. Frequency of synaptic autoantibody accompaniments and neurological manifestations of thymoma. JAMA Neurol 2016;73:853-859.

7. Lucchinetti CF, Kimmel DW, Lennon VA. Paraneoplastic and oncologic profiles of patients seropositive for type 1 antineuronal nuclear autoantibodies. Neurology 1998;50:652-657.

8. Alsharabati M, Oh SJ. Paraneoplastic myeloneuropathy in a man with breast cancer. Muscle Nerve 2015;52:685-686.

9. Rajabally YA, Qaddoura B, Abbott RJ. Steroid-responsive paraneoplastic demyelinating neuropathy and myelopathy associated with breast carcinoma. J Clin Neuromuscul Dis 2008;10:65-69.

10. Toso V, Cagnin G, Morello F, Antonini D, D’Este R. A case of paraneoplastic myeloneuropathy possibly of deficiency origin [in Italian]. Riv Neurobiol 1983;29:249-255.

11. Murphy SM, Khan U, Alifrangis C, et al. Anti Ma2-associated myeloradiculopathy: expanding the phenotype of anti-Ma2 associated paraneoplastic syndromes. J Neurol Neurosurg Psychiatry 2012;83:232-233.

12. Hirata A, Nomoto N, Konno S, et al. Subacute combined degeneration of the spinal cord concomitant with gastric cancer. Intern Med 2006;45:875-877.

13. Madrid A, Casado JL, Perez-Errazquin F, Vazquez A, Garzon F, Gil-Peralta A. Subacute combined degeneration of the spinal cord: manifestations of esophageal epidermoid carcinoma [in Spanish]. Rev Neurol 1997;25:1098-1101.

14. Berger B, Bischler P, Dersch R, Hottenrott T, Rauer S, Stich O. "Non-classical" paraneoplastic neurological syndromes associated with well-characterized antineuronal antibodies as compared to "classical" syndromes: more frequent than expected. J Neurol Sci 2015;352:58-61.

15. Dubey D, Jitprapaikulsan J, Bi H, et al. Amphiphysin-IgG autoimmune neuropathy: a recognizable clinicopathologic syndrome. Neurology 2019;93:e1873-e1880.

16. Flanagan EP, McKeon A, Lennon VA, et al. Paraneoplastic isolated myelopathy: clinical course and neuroimaging clues. Neurology 2011;76:2089-2095.

17. Sechi E, Morris PP, McKeon A, et al. Glial fibrillary acidic protein IgG related myelitis characterisation and comparison with aquaporin-4-IgG myelitis. J Neurol Neurosurg Psychiatry 2019;90:488-490.

18. Dubey D, Lennon VA, Gadoth A, et al. Autoimmune CRMP5 neuropathy phenotype and outcome defined from 105 cases. Neurology 2018;90:e103-e110.

19. Pittock SJ, Lucchinetti CF, Parisi JE, et al. Amphiphysin autoimmunity: paraneoplastic accompaniments. Ann Neurol 2005;58:96-107.

20. Gadoth A, Kryzer TJ, Fryer J, McKeon A, Lennon VA, Pittock SJ. Microtubule-associated protein 1B: novel paraneoplastic biomarker. Ann Neurol 2017;81:266-277.

21. Murphy BL, Zalewski NL, Degnim AC, et al. Breast cancer-related paraneoplastic neurologic disease. Breast Cancer Res Treat 2018;167:771-778. 
22. Mandel-Brehm C, Dubey D, Kryzer TJ, et al. Kelch-like protein 11 antibodies in seminoma-associated paraneoplastic encephalitis. N Engl J Med 2019;381:47-54.

23. Zekeridou A, Majed M, Heliopoulos I, Lennon VA. Paraneoplastic autoimmunity and small-cell lung cancer: neurological and serological accompaniments. Thorac Cancer 2019;10:1001-1004.

24. Pittock SJ, Kryzer TJ, Lennon VA. Paraneoplastic antibodies coexist and predict cancer, not neurological syndrome. Ann Neurol 2004;56:715-719.

25. Jitprapaikulsan J, Klein CJ, Pittock SJ, et al. Phenotypic presentations of paraneoplastic neuropathies associated with MAP1B-IgG. J Neurol Neurosurg Psychiatry 2020;91:328-330.

26. Dubey D, Wilson MR, Clarkson B, et al. Expanded clinical phenotype, oncological associations, and immunopathologic insights of paraneoplastic kelch-like protein-11 encephalitis. JAMA Neurol Epub 2020 Aug 3.

27. Karlsson AK. Autonomic dysfunction in spinal cord injury: clinical presentation of symptoms and signs. Prog Brain Res 2006;152:1-8.

28. Honorat JA, Lopez-Chiriboga AS, Kryzer TJ, et al. Autoimmune gait disturbance accompanying adaptor protein-3B2-IgG. Neurology 2019;93:e954-e963.

29. Verma R, Lalla R, Patil TB, Mehta V. Acute myeloneuropathy: an uncommon presentation of Sjogren's syndrome. Ann Indian Acad Neurol 2013;16:696-698.

30. Vernino S, Lennon VA. New Purkinje cell antibody (PCA-2): marker of lung cancerrelated neurological autoimmunity. Ann Neurol 2000;47:297-305

31. Rousseau A, Benyahia B, Dalmau J, et al. T cell response to Hu-D peptides in patients with anti-Hu syndrome. J Neurooncol 2005;71:231-236.
32. Cross SA, Salomao DR, Parisi JE, et al. Paraneoplastic autoimmune optic neuritis with retinitis defined by CRMP-5-IgG. Ann Neurol 2003;54:38-50.

33. Cook M, Baker K, Redman M, et al. Differential outcomes among immunosuppressed patients with merkel cell carcinoma: impact of immunosuppression type on cancerspecific and overall survival. Am J Clin Oncol 2019;42:82-88.

34. Vernino S, O’Neill BP, Marks RS, O’Fallon JR, Kimmel DW. Immunomodulatory treatment trial for paraneoplastic neurological disorders. Neuro Oncol 2004;6:55-62.

35. Mele N, Berzero G, Maisonobe T, et al. Motor neuron disease of paraneoplastic origin: a rare but treatable condition. J Neurol 2018;265:1590-1599.

36. Filippi M, Preziosa P, Banwell BL, et al. Assessment of lesions on magnetic resonance imaging in multiple sclerosis: practical guidelines. Brain 2019;142:1858-1875.

37. Jurynczyk M, Geraldes R, Probert F, et al. Distinct brain imaging characteristics of autoantibody-mediated CNS conditions and multiple sclerosis. Brain 2017;140:617-627.

38. Kumar N, Ahlskog JE, Klein CJ, Port JD. Imaging features of copper deficiency myelopathy: a study of 25 cases. Neuroradiology 2006;48:78-83

39. Kumar N, Gross JB Jr, Ahlskog JE. Copper deficiency myelopathy produces a clinical picture like subacute combined degeneration. Neurology 2004;63:33-39.

40. Titulaer MJ, Wirtz PW, Willems LN, van Kralingen KW, Smitt PA, Verschuuren JJ. Screening for small-cell lung cancer: a follow-up study of patients with Lambert-Eaton myasthenic syndrome. J Clin Oncol 2008;26:4276-4281.

41. Rosenfeld MR, Dalmau JO. Paraneoplastic disorders of the CNS and autoimmune synaptic encephalitis. Continuum 2012;18:366-383. 


\section{Neurology}

\section{Paraneoplastic Myeloneuropathies: Clinical, Oncologic, and Serologic Accompaniments}

Shailee Shah, Rocio Vazquez Do Campo, Neeraj Kumar, et al.

Neurology 2021;96;e632-e639 Published Online before print November 18, 2020

DOI 10.1212/WNL.0000000000011218

This information is current as of November 18, 2020

\section{Updated Information \&} Services

References

Subspecialty Collections

Permissions \& Licensing

Reprints including high resolution figures, can be found at: http://n.neurology.org/content/96/4/e632.full

This article cites 40 articles, 11 of which you can access for free at: http://n.neurology.org/content/96/4/e632.full\#ref-list-1

This article, along with others on similar topics, appears in the following collection(s):

Autoimmune diseases

http://n.neurology.org/cgi/collection/autoimmune_diseases

Paraneoplastic syndrome

http://n.neurology.org/cgi/collection/paraneoplastic_syndrome

Peripheral neuropathy

http://n.neurology.org/cgi/collection/peripheral_neuropathy

Transverse myelitis

http://n.neurology.org/cgi/collection/transverse_myelitis

Information about reproducing this article in parts (figures,tables) or in its entirety can be found online at:

http://www.neurology.org/about/about_the_journal\#permissions

Information about ordering reprints can be found online:

http://n.neurology.org/subscribers/advertise

Neurology ${ }^{\circledR}$ is the official journal of the American Academy of Neurology. Published continuously since 1951 , it is now a weekly with 48 issues per year. Copyright Copyright (C) 2020 The Author(s). Published by Wolters Kluwer Health, Inc. on behalf of the American Academy of Neurology.. All rights reserved. Print ISSN: 0028-3878. Online ISSN: 1526-632X.

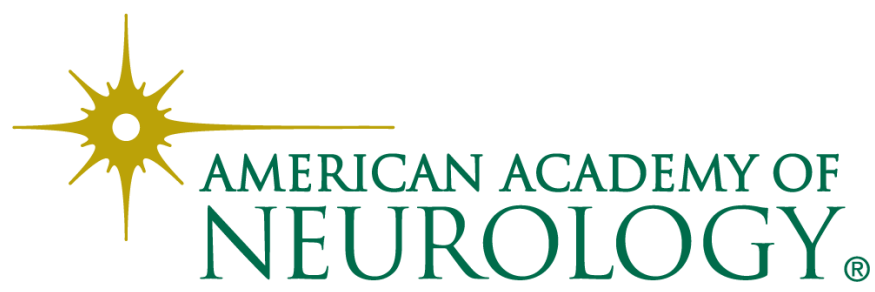

